\title{
Histidine Requirement of Cultivable Fish Species: A Review
}

\author{
Mukhtar A. Khan \\ Department of Zoology, Aligarh Muslim University, India
}

Submission: December 03, 2018; Published: December 11, 2018

Corresponding author: Mukhtar A Khan, Department of Zoology, Aligarh Muslim University, Aligarh, Uttar Pradesh, India

\section{Abstract}

Availability of nutritionally balanced commercial feeds is essential in producing healthy, high-quality aquatic animals. Protein is the most important component of aquaculture feeds. Fish require not only a minimum level of protein but also that the essential amino acids are balanced to meet the requirements of each single one. Histidine is an essential amino acid with several functions including protein synthesis, tissue formation and repair as well as maintenance of osmoregulation and myelin sheaths. It also regulates the immune system and acts as antioxidant in fish. Histidine deficiency depresses growth performance and feed utilization. If in excess, it causes disruption of the balance of dietary amino acids leading to toxicity or extensive necrosis in the epithelial cells. Furthermore, histidine serves as an important antioxidant and buffer in various organs of several fish species. In aquaculture, extensive research has been carried out to optimize the levels of histidine in the commercial diets for many fish species. Providing adequate levels of this amino acid is critically important for fish growth. Currently, available data suggest a wide variation in histidine requirements of different species ranging between $0.89-3.54 \%$ on protein basis.

Keywords: Histidine; Requirements; Fish; Deficiency; Toxicity; Antioxidant Response; Body Composition.

\section{Introduction}

Fish meal is the most attractive protein source for aquaculture diets because of its high protein content, well balanced amino acid, fatty acid composition, high digestibility and palatability. However, the high cost of fish meal and lack of availability are making it impracticable to use in all aquafeeds [1-4]. Therefore, fish meal needs to be replaced by more economical alternatives feed ingredients of plant origin in order to improve the economical sustainability of aquaculture. Various scientist has evaluated efficiency and possibility of using plant protein sources as a partial [3-31] or complete replacement of fish meal in fish diets [32-44]. Most of the plant protein sources are deficient in one or more essential amino acids. Thus, there is a dire need to supplement the essential amino acid in plant protein sources containing deficient amount of amino acid.

\section{Importance of Histidine}

Histidine is an essential amino acid for hemoglobin synthesis in aquatic and terrestrial animals and is important for growth, tissue formation and repair as well as for the maintenance of osmoregulation and myelin sheaths that act as protectors for nerve cells $[45,46]$. It serves as an important antioxidant and buffer in various organs of different fish species [47-49]. It is a major component of non-carbonated buffering against $\mathrm{pH}$ changes in fish muscle [50]. Muscle buffering prevents acidosis caused by anaerobic metabolism in white muscle [51]. Histidine and its related imidazole derivatives confer desirable taste and texture and dietary supplementation of histidine can improve sensory attributes such as flavor of the aquaculture seafoods [51]. Additionally, Forde-Skjaevik et al. [52] reported that dietary supplementation of histidine increases intramuscular histidine levels and $\mathrm{pH}$, while reducing muscle gapping in Atlantic cod post-mortem. Positive action of histidine on the uptake of zinc in rainbow trout was reported by Glover et al. [53] whereas dietary zinc supplementation could improve the activities of intestinal digestive enzymes in juvenile Jian carp [54]. Another aspect of histidine stress mitigation is antioxidant status. Superoxide scavenging ability was also enhanced by histidine supplementation. Boldyrev \& Severin and Bjerkas \& Sveier $[55,56]$ reported that histidine and histidine-related compounds such as anserine and carnosine have been found to act as antioxidants in the lens of an eye. Son et al. [57] reported that histidine could inhibit the inflammation induced by oxidative stress in human intestinal epithelial cells. Moreover, dietary histidine enhances the glutamate pyruvate transaminase (GPT) activities both in hepatopancreas and muscle up to a certain level [58]. A possible explanation could be that GPT is related to the synthesis of carnosine (b-alanine-L-histidine) which is an important metabolism product of histidine and is mainly synthesized from its constituent amino acids in muscle and liver [59].

\section{Histidine Content in Feed Ingredients \& Histidine Requirement}

Since histidine is an essential amino acid, dietary inclusion is the main source of histidine for successful culture of several 
cultivable fish species. The content of histidine of various feed ingredients were recorded in the range of $0.89-3.54 \%$ on protein basis [60]. The ingredients such as fish meal containing salmon byproduct $3.51 \%$, rice protein concentrate $2.02 \%$, wheat, soft grain $2 \%$, pea protein concentrate $2.49 \%$, soybean meal protein concentrate $2.50 \%$, rice bran $2.61 \%$, wheat flour $3.54 \%$, rice bran with germ, solvent extracted $1.93 \%$, rice polishing $2.15 \%$, wheat bran $2.14 \%$, rice broken with polishing $2.57 \%$ and white fishmeal $2.16 \%$ and meat and bone meal $2 \%$ on protein basis are feedstuffs with high histidine content, whereas whey dried $1.68 \%$, poultry byproduct meal, feed grade low as $1.88 \%$, poultry byproduct meal $1.90 \%$, oats $1.63 \%$, gelatin $0.89 \%$ and hydrolyzed poultry feather meal $0.84 \%$ on protein basis have lower histidine content. The efficient use of such protein sources in fish feeds depends on appropriate supplementation of histidine to meet the requirements.

Histidine requirement have been determined for several cultivable fish species and are found to range between $0.9-4.8 \%$ of dietary protein (Table 1). The reported dietary histidine requirements among different species show a wide variation with some contradictions in the data on dietary histidine requirements for certain species. For instance, dietary histidine requirements have been established for a number of cultured fish species, such as $1.54 \%$ channel catfish Ictalurus punctatus [61]; 1.6\% Chum salmon Oncorhynchus keta [62]; 1.7 \% gilthead sea bream Sparus auratus [63]; 1.1\% rainbow trout Oncorhynchys mykiss [64]; 2.1\% Mrigal carp Cirrhinus mrigala [65]; 1.0\% African catfish Clarias gariepinus [66]; 3.51\% Stinging catfish Heteropneustes fossilis [67], 3.6\% Singhi, Heteropneustes fossilis [68]; 2.38\% Cyprinus carpio, 2.1\% C. carpio [69] and 3.2\% juvenile Grass carp Ctenopharyngodon idella [70]; 3.1\% blunt snout bream Megalobrama amblycepahala [71]; 3.1\% Nile tilapia Oreochromis niloticus [72] of dietary protein.

\section{Deficiency Signs \& Toxicity}

If histidine is not adequately balanced in feeds, deficiency signs and the toxicity may develop. The deficiency of dietary histidine leads to reduced growth, cataract, incidence of lordosis, anorexia, allergic reaction, gastric acid secretion and high stress response [58-75]. The lower feed intake in fish fed diet containing deficient amounts of histidine has also been reported which may be due to the reason that after ingesting an amino acid imbalanced diet, animal first recognizes the amino acid deficiency and then respond by reducing their feed intake [76]. The cataract mitigating ability of histidine is due to $\mathrm{N}$-acetyl histidine that is synthesized in the lens. Peachey et al. [77] found significantly higher histidine in

Table 1: Histidine requirements of various cultivable fish species.

\begin{tabular}{|c|c|c|c|c|c|c|}
\hline \multirow{2}{*}{ Species } & $\begin{array}{c}\text { Crude protein } \\
\text { (\% of dry diet) }\end{array}$ & $\begin{array}{c}\text { Histidine requirement } \\
\text { (\% of dietary protein) }\end{array}$ & $\begin{array}{c}\text { Criteria for require- } \\
\text { ment determination }\end{array}$ & Fish weight (g) & $\begin{array}{c}\text { Dietary pro- } \\
\text { tein source }\end{array}$ & References \\
\hline \multirow{2}{*}{ Anguilla japonica } & 30 & 2.1 & & & & {$[86]$} \\
\hline \multirow{2}{*}{ Catla } & 40 & 2.5 & & & CS; GL; AA & {$[78]$} \\
\cline { 2 - 7 } & 33 & 2.06 & AWG;FCR;PG & 0.65 & CS; GL; AA & {$[87]$} \\
\hline
\end{tabular}

lenses in fish fed adequate histidine when compared to histidinedeficient fish. Moreover, excessive histidine inhibited the growth of African catfish Clarias gariepinus [66], Indian major carp, $C$. catla [78], and rohu, Labeo rohita [79]. This may have occurred because excessive histidine disrupted the balance of dietary amino acids leading to toxicity in the tissues, [80] or extensive necrosis in the epithelial cells of the hepatopancreas [81] thereby influencing fish growth. Increases in free histidine could cause elevated histamine production, and excess histamine could induce proinflammatory cytokines, possibly disturbing the erythrocytes [82]. Erythrocyte osmotic fragility was significantly higher in fish fed the histidine-sufficient diet compared to those fed the histidine-deficient diet. Erythrocyte osmotic fragility, which quantifies the amount of hemolysis occurring when erythrocytes are subjected to osmotic stress, can be viewed as a measure of the quality of the erythrocytes and the integrity of their membranes. Erythrocytes break down was reported to be faster in case of improper membrane function [83]. In grass carp (Gao et al., 2016 and stinging catfish [67], erythrocyte fragility was significantly affected by dietary histidine. Arop et al. [71] reported that the relative gene expression of TOR mRNA in the liver of blunt snout bream was increased with increasing dietary histidine levels up to $9.9 \mathrm{~g} / \mathrm{kg}$, and it declined thereafter as dietary histidine levels increased. Similar trends were found in the gills of grass carp fed with graded levels of histidine [82].

\section{Effects on Body Composition}

Histidine supplementation has also been reported to affect the carcass quality, which is the most important issue for aqua culturists as it influences the yield of final product. Therefore, research has largely been focused on the means to improve the carcass quality and the efficiency of nutrient utilization for muscle growth. Since a major and most important component of tissue is protein, priority is given to increase the quantity and improve the tissue quality of protein. Histidine supplementation positively increased protein content of the whole body of the fish [58-66]. Several studies indicated that the protein content in the whole body increased with the increase in dietary histidine level and decreased significantly when dietary histidine was higher than the optimal requirement $(46,65,66,68,72,84)$. However, whole body composition and muscle composition was not significantly affected by dietary histidine levels in yellow croaker [85], grass carp [50], singhi [68], and red drum [77]. Dietary histidine has been reported to reduce body fat in several fish species [60,67]. Since histidine deficiency causes reduced growth and cataract, it is necessary to ensure the optimum inclusion of dietary histidine to improve the fish growth performance [86-98] [Table 1]. 
Oceanography \& Fisheries Open access Journal

\begin{tabular}{|c|c|c|c|c|c|c|}
\hline Chanos chanos & 40 & 2 & WG;FE;SR & $\leq 8.0$ & $\mathrm{CS} ; \mathrm{GL} ; \mathrm{FM}$ & [88] \\
\hline Cirrhinus mrigala & 40 & 2.1 & LWG;FCR;PER & 0.6 & $\mathrm{CS} ; \mathrm{GL} ; \mathrm{AA}$ & [65] \\
\hline Clarias gariepinus & 40 & 1.5 & $\begin{array}{l}\text { AWG;FCR;PER;S- } \\
\text { GR;PRE }\end{array}$ & 0.2 & $\mathrm{CS} ; \mathrm{GL} ; \mathrm{AA}$ & [66] \\
\hline $\begin{array}{l}\text { Clarias macro- } \\
\text { cephalus x Clarias } \\
\text { gariepinus }\end{array}$ & & 1.2 & & & & [89] \\
\hline \multirow{3}{*}{ Cyprinus carpio } & 32 & 2.3 & SGR;FE;PER & 8.7 & FM;GL;AA & [58] \\
\hline & 48 & 2.1 & WG & 1.7 & & [90] \\
\hline & 40 & 4.8 & & & & [91] \\
\hline $\begin{array}{c}\text { Ctenopharyngodon } \\
\text { idella }\end{array}$ & 38 & 3.2 & WG; SGR; FCR; FI & 3.68 & $\mathrm{CS} ; \mathrm{GL} ; \mathrm{AA}$ & [50] \\
\hline Dicentrarchus labrax & 62 & 1.64 & & & & [63] \\
\hline \multirow{3}{*}{$\begin{array}{l}\text { Heteropneustes } \\
\text { fossilis }\end{array}$} & 38 & 2.48 & AWG;PG;FCR & 6.6 & $\mathrm{CS} ; \mathrm{GL} ; \mathrm{AA}$ & [67] \\
\hline & 43 & 3.5 & LWG; FCR;PER;PRE & 5.2 & $\mathrm{CS} ; \mathrm{GL} ; \mathrm{AA}$ & [68] \\
\hline & 40 & 1.35 & LWG; FCR;PER & 4.6 & CS; GL; AA & [46] \\
\hline Ictalurus punctatus & 24 & 1.5 & WG & 200 & $\mathrm{CS} ; \mathrm{GL} ; \mathrm{AA}$ & [61] \\
\hline \multirow{2}{*}{ Labeo rohita } & 40 & 2.25 & WG;SGR;FCR & & $\mathrm{CS} ; \mathrm{GL} ; \mathrm{AA}$ & [79] \\
\hline & 40 & 2.25 & LWG;SGR;FCR;PER & 3.5 & $\mathrm{CS} ; \mathrm{GL} ; \mathrm{AA}$ & [84] \\
\hline $\begin{array}{l}\text { Megalobrama am- } \\
\text { blycephala }\end{array}$ & 33 & 3.6 & WG;SGR;FCR SR & 23.3 & FM;CS;GL;AA & [71] \\
\hline $\begin{array}{l}\text { Onchorhynchus } \\
\text { tshawytscha }\end{array}$ & 40 & 1.8 & GAIN; FEED/GAIN & 2.9 & $\mathrm{CS} ; \mathrm{GL} ; \mathrm{AA}$ & [92] \\
\hline \multirow{2}{*}{ Oncorhynchus kisutch } & 40 & 1.8 & GAIN; FEED/GAIN & 3.1 & $\mathrm{CS} ; \mathrm{GL} ; \mathrm{AA}$ & [92] \\
\hline & & 0.9 & & & & [93] \\
\hline \multirow{2}{*}{ Onchorhynchus keta } & 40 & 1.6 & WG & 1.5 & $\mathrm{CS} ; \mathrm{GL} ; \mathrm{AA}$ & [62] \\
\hline & & 1.6 & & & & [94] \\
\hline \multirow{3}{*}{ Oreochromis niloticus } & 26 & 3.1 & WG; FCR;PER & 4.8 & $\begin{array}{l}\text { RC;MBM;PB- } \\
\text { M;FEM }\end{array}$ & [72] \\
\hline & 34 & 1.1 .2 & WG;PD & 40 & WG;AA & [64] \\
\hline & 28 & 1.7 & WG & 0.08 & CS;GL;AA & [95] \\
\hline Oncorhynchus mykiss & 40 & 1.6 & & & & [91] \\
\hline Pseudosciaena crocea & 44 & 2.0 & WG;FE;SR & 6 & FM; CG;GL & [85] \\
\hline \multirow{2}{*}{ Salmo salar } & 40 & 2.0 & LWG;FCR;SGR & 62 & $\mathrm{CS} ; \mathrm{CG}$ & [96] \\
\hline & 45 & 4.0 & & & & [97] \\
\hline \multirow[b]{2}{*}{ Sciaenops ocellatus } & 35 & 1.7 & & & & [98] \\
\hline & 35 & 1.6 & $\begin{array}{c}\text { RWG; FER; PER;PR; } \\
\text { PH }\end{array}$ & 0.98 & $\mathrm{RDM} ; \mathrm{AA}$ & [77] \\
\hline $\begin{array}{l}\text { Scophthalmus max- } \\
\text { imus }\end{array}$ & 70 & 1.5 & & & & [63] \\
\hline \multirow{2}{*}{ Sparus aurata } & 57 & 1.7 & & & & [63] \\
\hline & $40: 36$ & 3.5 & LWG;DDP & 2.2 & FM;SB;WB & [99] \\
\hline
\end{tabular}

LWG: live weight gain; WG: weight gain; SGR: specific growth rate; FCR: feed conversion ratio; PER: protein efficiency ratio; PRE: protein retention efficiency; FE: feed efficiency; DDP: daily deposition; SR: survival; WGM: wheat gluten meal; FEM: feather meal; RC: rice; SB: soybean meal; FM: fish meal; MBM: meat and bone meal; WB: wheat bran; PBM: poultry by product meal ; CS: casein; GL: gelatin; AA: amino acids mixture; RDM: red drum meal; $\mathrm{PH}$; plasma histidine.

\section{References}

1. Rathinam MM, Kizhakudan JK, Vijayagopal P, Jayasankar VAL, Sundar $\mathrm{R}$ (2014) Effect of dietary protein levels in the formulated diets on growth and survival of juvenile spiny lobster Panulirus homarus (Linnaeus). Indian Journal of Fisheries 61(2): 67-72.
2. Azevedo PA, Cho CY, Lesson S, Bureau DP (1998) Effects of feeding level and water temperature on growth, nutrient utilization and waste outputs of rainbow trout (Oncorhynchus mykiss). Aquatic Living Resources 11(4): 227-238.

3. Kurbanov AR, Rakiya Yu Milusheva, Sayera Sh Rashidova, Bakhtiyar G Kamilov (2015) Effect of replacement of fish meal with silkworm 
(Bombyx mori) pupa protein on the growth of Clarias gariepinus fingerling. International Journal of Fisheries and Aquatic Studies 2(6): 25-27.

4. Nunes APJ, Sá MCV, Browdy CL, Anon MV (2014) Practical supplementation of shrimp and fish feeds with crystalline amino acids. Aquaculture 431: 20-27.

5. Cheng ZJ, Hardy RW, Usry JL (2003) Plant protein ingredients with lysine supplementation reduce dietary protein level in rainbow trout (Oncorhynchus mykiss) diets, and reduce ammonia nitrogen and soluble phosphorus excretion. Aquaculture 218(1-4): 553-565.

6. Kaushik SJ, Coves D, Dutto G, Blanc D (2004) Almost total replacement of fish meal by plant protein sources in the diet of a marine teleost, the European seabass, Dicentrarchus labrax. Aquaculture 230(1-4): 391404.

7. De Francesco M, Parisi G, Pérez-Sanchez J, Gomez-Réqueni P, Medale F, et al. (2007) Effect of high-level fish meal replacement by plant proteins in gilthead sea bream (Sparus aurata) on growth and body/ fillet quality traits. Aquaculture Nutrition 13(5): 361-372.

8. Hansen AC, Rosenlund G, Karlsen O, Koppe W, Hemre GI (2007) Total replacement of fish meal with plant proteins in diets for Atlantic cod (Gadus morhua L) I-Effects on growth and protein retention. Aquaculture 272(1-4): 599-611.

9. Suárez JA, Gaxiola G, Mendoza R, Cadavid S, Garcia G, et al. (2009) Substitution of fish meal with plant protein sources and energy budget for white shrimp Litopenaeus vannamei (Boone, 1931). Aquaculture 289(1-2): 118-123.

10. Salze G, McLean E, Battle PR, Schwarz MH, Craig SR (2010) Use of soy protein concentrate and novel ingredients in the total elimination of fish meal and fish oil in diets for juvenile cobia, Rachycentron canadum. Aquaculture 298(3-4): 294-299.

11. Bonaldo A, Luca P, Luciana M, Rubina S, Ramon F (2011) Increasing dietary plant proteins affects growth performance and ammonia excretion but not digestibility and gut histology in turbot (Psetta maxima) juveniles. Aquaculture 318(1-2): 101-108.

12. Lund I, Dalsgaard J, Rasmussen HT, Holm J, Jokumsen A (2011) Replacement of fish meal with a matrix of organic plant proteins in organic trout (Oncorhynchus mykiss) feed, and the effects on nutrient utilization and fish performance. Aquaculture 321(3-4): 259-266.

13. Richard L, Surget A, Rigolet V, Kaushik SJ, Geurden I (2011) Availability of essential amino acids, nutrient utilisation and growth in juvenile black tiger shrimp, Penaeus monodon, following fishmeal replacement by plant protein. Aquaculture 322(323): 109-116.

14. Köprücü K, Sertel E (2012) The effects of less-expensive plant protein sources replaced with soybean meal in the juvenile diet of grass carp (Ctenopharyngodon idella): growth, nutrient utilization and body composition. Aquaculture International 20(3): 399-412.

15. Sicuro B, Gai F, Daprà F, Palmegiano GB (2012) Hybrid sturgeon 'AL' (Acipenser naccarii $\times$ Acipenser baeri) diets: the use of alternative plant protein sources. Aquaculture Research 43(2): 161-166.

16. Bulbul M, Koshio S, Ishikawa M, Yokoyama S, Kader MA (2013) Performance of kuruma shrimp, Marsupenaeus japonicus fed diets replacing fishmeal with a combination of plant protein meals. Aquaculture 372-375: 45-51.

17. Cabral EM, Fernandes TJ, Campos SD, Castro-Cunha M, Oliveira MB, et al. (2013) Replacement of fish meal by plant protein sources up to $75 \%$ induces good growth performance without affecting flesh quality in on growing Senegalese sole. Aquaculture 380(383): 130-138.

18. Rossi W, Moxely D, Buentello A, Pohlenz C, Gatlin DM (2013) Replacement of fishmeal with novel plant feedstuffs in the diet of red drum Sciaenops ocellatus: an assessment of nutritional value. Aquaculture Nutrition 19(s1): 72-81.
19. Azarm HM, Lee SM (2014) Effects of partial substitution of dietary fish meal by fermented soybean meal on growth performance, amino acid and biochemical parameters of juvenile black sea bream Acanthopagrus schlegell. Aquaculture Research 45(6): 994-1003.

20. Murray DS, Hager H, Tocher DR, Kainz MJ (2014) Effect of partial replacement of dietary fish meal and oil by pumpkin kernel cake and rapeseed oil on fatty acid composition and metabolism in Arctic charr (Salvelinus alpinus). Aquaculture 431: 85-91.

21. Yu DH, Gong SY, Lin YC, Yuan YC (2014) Partial replacement of fish meal by several plant proteins with or without iron and lysine supplement in diets for juvenile Chinese sucker, Myxocyprinus asiaticus. Aquaculture Nutrition 20(2): 205-212.

22. Rodiles A, Herrera M, Hachero-Cruzado I, Ruiz-Jarabo I, Mancera JM, et al. (2015) Tissue composition, blood biochemistry and histology of digestive organs in Senegalese sole (Solea senegalensis) juveniles fed diets containing different plant protein ingredients. Aquaculture Nutrition 21(6): 767-779.

23. Suprayudi MA, Inara C, Ekasari J, Priyoutomo N, Haga Y, et al. (2015) Preliminary nutritional evaluation of rubber seed and defatted rubber seed meals as plant protein sources for common carp Cyprinus carpio L juvenile diet. Aquaculture Research 46(12): 2972-2981.

24. Bonaldo A, Di Marco P, Petochi T, Marino G, Parma L, et al. (2015) Feeding turbot juveniles Psetta maxima L with increasing dietary plant protein levels affects growth performance and fish welfare. Aquaculture Nutrition 21(4): 401-413.

25. Dawood MAO, Koshio S, Ishikawa M, Yokoyama S (2015) Effects of Partial Substitution of Fish Meal by Soybean Meal with or without Heat-Killed Lactobacillus plantarum (LP20) on Growth Performance, Digestibility, and Immune Response of Amberjack, Seriola dumerili Juveniles. BioMed Research International 11: 514196.

26. Kissinger KR, Garcia-Ortega A, Trushenski JT (2016) Partial fish meal replacement by soy protein concentrate, squid and algal meals in low fish-oil diets containing Schizochytrium limacinum for longfin yellowtail Seriola rivoliana. Aquaculture 452: 37-44.

27. Minjarez-Osorio C, Castillo-Alvarado S, Gatlin DM, González-Félix ML, Perez-Velazquez M, et al. (2016) Plant protein sources in the diets of the sciaenids red drum (Sciaenops ocellatus) and shortfin corvina (Cynoscion parvipinnis): A comparative study. Aquaculture 453: 122129.

28. Valente LM, Cabral EM, Sousa V, Cunha LM, Fernandes JM (2016) Plant protein blends in diets for Senegalese sole affect skeletal muscle growth, flesh texture and the expression of related genes. Aquaculture 453: 77-85.

29. Xie SW, Liu YJ, Zeng S, Niu J, Tian LX (2016) Partial replacement of fish-meal by soy protein concentrate and soybean meal-based protein blend for juvenile Pacific white shrimp, Litopenaeus vannamei. Aquaculture 464: 296-302.

30. Moutinho S, Martinez-Llorens S, Tomas-Vidal A, Jover-Cerda M, OlivaTeles A, et al. (2017) Meat and bone meal as partial replacement for fish meal in diets for gilthead seabream (Sparus aurata) juveniles: Growth, feed efficiency, amino acid utilization, and economic efficiency. Aquaculture 468: 271-277.

31. Anh NTN, Hai TN, Hien TTT (2018) Effects of partial replacement of fishmeal protein with green seaweed (Cladophora spp.) protein in practical diets for the black tiger shrimp (Penaeus monodon) postlarvae. Journal of Applied Phycology 30(4): 2649-2658.

32. Gómez-Requeni P, Mingarro M, Calduch-Giner JA, Médale F, Martin SA et al. (2004) Protein growth performance, amino acid utilisation and somatotropic axis responsiveness to fish meal replacement by plant protein sources in gilthead sea bream (Sparus aurata). Aquaculture 232(1-4): 493-510. 
33. Liti DM, Waidbacher H, Straif M, Mbaluka RK, Munguti JM, et al. (2006) Effects of partial and complete replacement of freshwater shrimp meal (Caridinea niloticus Roux) with a mixture of plant protein sources on growth performance of Nile tilapia (Oreochromis niloticus L) in fertilized ponds. Aquaculture Research 37(5): 477-483.

34. Cho SH (2010) Effect of fishmeal substitution with various animal and/or plant protein sources in the diet of the abalone Haliotis discus hannai Ino. Aquaculture Research 41(10): e587-e593.

35. Lee KJ, Powell MS, Barrows FT, Smiley S, Bechtel P, et al. (2010) Evaluation of supplemental fish bone meal made from Alaska seafood processing by products and dicalcium phosphate in plant proteinbased diets for rainbow trout (Oncorhynchus mykiss). Aquaculture 302(3): 248-255.

36. Zhang Y, Overland M, Shearer KD, Mydland LT, Storebakken T, et al. (2012) Optimizing plant protein combinations in fish meal-free diets for rainbow trout (Oncorhynchus mykiss) by a mixture model. Aquaculture 360-361: 25-36.

37. Yun B, Xue M, Wang J, Sheng H, Zheng Y, et al. (2014) Fishmeal can be totally replaced by plant protein blend at two protein levels in diets of juvenile Siberian sturgeon, Acipenser baerii. Aquaculture Nutrition 20(1): 69-78.

38. Ibrahem MD, Ibrahim MA (2014) The potential effects of Spirulina platensis (Arthrospira platensis) on tissue protection of Nile tilapia (Oreochromis niloticus) through estimation of P53 level. Journal of Advanced Research 5(1): 133-136.

39. Mahboob S (2014) Replacing fish meal with a blend of alternative plant proteins and its effect on the growth performance of Catla catla and Hypophthalmichthys molitrix. Pakistan Journal of Zoology 46(3): 747 752.

40. Yıldırım Ö, Acar Ü, Türker A, Sunar MC, Kesbic SO (2014) Effects of Replacing Fish Meal with Peanut Meal (Arachis hypogaea) on Growth, Feed Utilization and Body Composition of Mozambique Tilapia Fries (Oreochromis mossambicus). Pakistan Journal of Zoology 46(2): 497 502 .

41. Wu Y, Han H, Qian J, Wang Y (2015) Replacement of fishmeal by soy protein concentrate with taurine supplementation in diets for golden pompano (Trachinotus ovatus). Aquaculture Nutrition 21(2): 214-222.

42. Thobaitia A, Al-Ghanima K, Ahmeda Z, Sulimana EM, Mahboob S (2018) Impact of replacing fish meal by a mixture of different plant protein sources on the growth performance in Nile Tilapia (Oreochromis niloticus L) diets. Braz J Biol 78(3): 525-534.

43. Lazzarotto V, Medale F, Larroquet L, Corraze G (2018) Long-term dietary replacement of fishmeal and fish oil in diets for rainbow trout (Oncorhynchus mykiss): Effects on growth, whole body fatty acids and intestinal and hepatic gene expression. PLOS ONE 13: e0190730.

44. Ma Zhenhua, Mahbubul Hassan, Allais L, He T, Leterme S, et al. (2018) Replacement of fishmeal with commercial soybean meal and Enzomeal in juvenile barramundi Lates calcarifer. Aquaculture Research 49(10): 3258-3269.

45. Nasset ES, Gatewood VH (1954) Nitrogen balance and hemoglobin of adult rats fed amino acid diets low in L- and D-histidine. Journal of Nutrition 53: 163-176.

46. Ahmed I (2013) Dietary amino acid L-histidine requirement of fingerling Indian catfish, Heteropneustes fossilis (Bloch), estimated by growth and whole body protein and fat composition. Journal of Applied Ichthyology 29(3): 602-609.

47. Hiroshi H, Murai T (1994) White muscle of masu salmon, Oncorhynchus masou masou, smolts possesses a strong buffering capacity due to a high level of anserine. Fish Physiology and Biochemistry 13: 285-293.

48. Munakata A, Aida K, Amano M, Ikuta K, Kitamura S, et al. (2000)
Changes in histidine and anserine levels in hatchery-reared honmasu salmon parr after release in a river. Journal of World Aquaculture Society 31(2): 274-278.

49. Wade MA, Tucker HN (1998) Antioxidant characteristics of L-histidine. Journal of Nutritional Biochemistry 9(6): 308-315.

50. Gao YJ, Jian Y, Chen XQL, Yang HJ, Li XF, et al. (2016) Effects of graded levels of histidine on growth performance, digested enzymes activities, erythrocyte osmotic fragility and hypoxia-tolerance of juvenile grass carp Ctenopharyngodon idella. Aquaculture 452: 388-394.

51. Ogata HY (2002) Muscle buffering capacity of yellowtail fed diets supplemented with crystalline histidine. Journal of Fish Biology 61(6): 1504-1512.

52. Forde-Skjærvik O, Skjærvik O, Morkore T, Thomassen MS, Rorvik KA (2006) Dietary influence on quality of farmed Atlantic cod (Gadus morhua): effect on glycolysis and buffering capacity in white muscle. Aquaculture 252(2-4): 409-420.

53. Glover CN, Bury NR, Hogstrand C (2003) Zinc uptake across the apical membrane of freshwater rainbow trout intestine is mediated by high affinity, low affinity, and histidine-facilitated pathways. Biochim Biophys Acta 1614(2): 211-219.

54. Tan LN, Feng L, Liu Y, Jiang J, Jiang WD, et al. (2011) Growth, body composition and intestinal enzyme activities of juvenile Jian carp (Cyprinus carpio var. Jian) fed graded levels of dietary zinc. Aquaculture Nutrition 17(3): 338-345.

55. Boldyrev AA, Severin SE (1990) The histidine-containing dipeptides, carnosine and anserine: distribution, properties and biological significance. Advances in Enzyme Regulation 30: 175-188.

56. Bjerkas E, Sveier H (2004) The influence of nutritional and environmental factors on osmoregulation and cataracts in Atlantic salmon (Salmo salar L.). Aquaculture 235(1-4): 101-122.

57. Son DO, Satsu H, Shimizu M (2005) Histidine inhibits oxidative stressand TNF-alpha-induced interleukin-8 secretion in intestinal epithelial cells. FEBS Lett 579(21): 4671-4677.

58. Zhao B, Feng L, Liu Y, Kuang SY, Tang L, et al. (2012) Effects of dietary histidine levels on growth performance, body composition and intestinal enzymes activities of juvenile Jian carp (Cyprinus carpio var. Jian). Aquaculture Nutrition 18(2): 220-232.

59. Stifel FB, Herman RH (1971) Histidine metabolism. American Journal of Clinical Nutrition 24: 207-217.

60. NRC National Research Council (2011) Nutrient Requirements of Fish and Shrimps. National Academy Press, Washington, DC, USA.

61. Wilson RP, Poe WE, Robinson EH (1980) Leucine, isoleucine, valine and histidine requirements of fingerling channel catfish. J Nut 110(4): 627-633.

62. Akiyama T, Arai S, Murai T (1985) Threonine, histidine and lysine requirements of chum salmon fry. NIPPON SUISAN GAKKAISHI 51(4): 635-639.

63. Kaushik SJ (1998) Whole body amino acid composition of European Seabass (Dicentrarchus labrax), gilthead seabream (Sparus aurata) and turbot (Psetta maxima) with an estimation of their IAA requirement profiles. Aquatic Living Resources 11(5): 355-358.

64. Rodehutscord M, Becker A, Pack M, Pfeffer E (1997) Response of rainbow trout (Oncorhynchus mykiss) to supplements of individual essential amino acids in a Semi purified diet, including an estimate of the maintenance requirement for essential amino acids. J Nutr 127(6): 1166-1175.

65. Ahmed I, Khan MA (2005) Dietary histidine requirement of fingerling Indian major carp, Cirrhinus mrigala (Hamilton). Aquaculture Nutrition 11(5): 359-366. 
66. Khan MA, Abidi SF (2009) Optimum histidine requirement of fry African catfish, Clarias gariepinus (Burchell). Aquaculture Research 40(9): 1000-1010.

67. Farhat, Khan, MA (2013) Effects of varying levels of dietary L-histidine on growth, feed conversion, protein gain, histidine retention, hematological and body composition in fingerlings stinging catfish, Heteropneustes fossilis (Bloch) Aquaculture 404-405: 130-138.

68. Khan MA, Abidi SF (2014) Dietary histidine requirement of Singhi, Heteropneustes fossilis fry (Bloch). Aquaculture Research 45(8): 13411345.

69. Nose T (1979) Summary report on the requirements of essential amino acids for carp. In: Halver JE, Tiews K (eds). Finfish Nutrition and Fish Feed Technology pp. 145-156.

70. Gao HN, Hu H, Zheng N, Wang JQ (2015) Leucine and histidine independently regulate milk protein synthesis in bovine mammary epithelial cells via mTOR signaling pathway. J Zhejiang Univ Sci B 16(6): 560-572

71. Arop OMW, Liang H, Ge X, Ren M, Habte-Tsion HM, et al. (2018) Dietary histidine requirement of juvenile blunt snout bream (Megalobrama amblycephala). Aquaculture Nutrition 24(3): 1122-1132.

72. Michelato MMZ, Wilson RB, Viviane N, Marcelo V, Roberto, FA, et al. (2017) Dietary histidine requirement of Nile tilapia juveniles based on growth performance, expression of muscle-growth-related genes and haematological responses. Aquaculture 467: 63-70.

73. Mazid MA, Tanaka Y, Katayama T, Simpson KL, Chichester CO (1978) Metabolism of amino acids in aquatic animals III Indispensable amino acids for Tilapia zilli. Nihon-suisan-gakkai-shi 44(7): 739-742.

74. Cofiel LPV, Mattioli R (2009) L-histidine enhances learning in stressed zebrafish. Braz J Med Biol Res 42(1): 128-134.

75. Yoshikawa T, Nakamura T, Shibakusa T, Sugita M, Naganuma F, et al. (2014) Insufficient intake of L-histidine reduces brain histamine and causes anxiety-like behaviors in male mice. J Nutr 144(10): 1637-1641.

76. Maurin AC, Bruhat A, Jousse C, Cherasse Y, Fafournoux P (2006) Cellular adaptation to amino acid availability: mechanism involved in the regulation of gene expression. In Bulletin de 'Academie Veterinaire de France 319-326.

77. Peachey BL, Scott EM, Gatlin DM III (2018) Dietary histidine requirement and physiological effects of dietary histidine deficiency in juvenile red drum Sciaenop ocellatus. Aquaculture 483: 244-251.

78. Ravi J, Devaraj KV (1991) Quantitative essential amino acid requirements for growth of catla, Catla catla (Hamilton). Aquaculture 96(3-4): 281-291.

79. Murthy H, Varghese T (1995) Arginine and histidine requirements of the Indian major carp, Labeo rohita (Hamilton). Aquaculture Nutrition 1(4): 235-239.

80. Mertz ET (1972) The protein and amino acid needs. In: Halver JE (Ed.), Fish Nutrition, Academic Press, New York, pp. 105-143.

81. Recodo AG (1991) Histophysiological effects of various histidine levels in the diet on the hepatopancreas of Penaeus monodon. Institute of Biology, College of Science, U.P. Diliman, Quezon City, Philippines, 104 pp.

82. Jiang WD, Feng L, Qu B, Wu P, Kuang SY, et al. (2016) Changes in integrity of the gill during histidine deficiency or excess due to depression of cellular anti-oxidative ability, induction of apoptosis, inflammation and impair of cell-cell tight junctions related to Nrf2: TOR and NF-B signaling in fish. Fish Shellfish Immunol 56: 111-122.

83. Robbins SL, Cotran RS, Kumar V (1984) Pathologic basis of disease. Saunders, Philadelphia, PA, pp. 1467.

84. Abidi SF, Khan MA (2004) Dietary histidine requirement of fingerling Indian major carp, Labeo rohita (Hamilton). Aquaculture Nutrition 13(6): 424-430.

85. Li Y, Cheng Z, Kangsen I, Ai QM (2014) Dietary Histidine Requirement for Juvenile Large Yellow Croaker, Pseudosciaena crocea R. The Israeli Journal of Aquaculture=Bamidgeh 66: 1-7.

86. Arai S, Nose T, Hashimoto Y (1979) Amino acid essential for the growth of eels, Anguilla anguilla and A. japonica. Nihon-suisan-gakkai-shi 38(7): 753-759.

87. Zehra S, Khan MA (2014) Dietary histidine requirement of fingerling Catla Catla (Hamilton) based on growth, protein gain, histidine gain, RNA/DNA ratio, haematological indices and carcass composition. Aquaculture Research 47(4): 1028-1039.

88. Borlongan IG, Coloso RM (1993) Requirements of juvenile milkfish (Chanos chanos Forsskal) for essential amino acids. J Nutr 123(1): 125132.

89. Unprasert NG (1994) An evaluation of the use of Ideal "protein" concept to estimate essential amino acid requirements of the Clarias hybrid (Clarias macrocephalus $\times$ Clarias gariepinus). Mississippi State University, Mississippi State, MS.

90. Ogino C (1980) Requirements of carp and rainbow trout for essential amino acids. Bulletin of the Japanese Society for the Science of Fish 46(2): 171-174.

91. Klein RG, Halver JE (1970) Nutrition of salmonid fishes: arginine and histidine requirements of chinook and coho salmon. Journal of Nutrition 100(9): 1105-1109.

92. Arai S, Ogata H (1993) Quantitative amino acid requirements of fingerling coho salmon. In: Collie MR, McVey JP (Eds), Proceedings of 20th US-Japan Symposium on Aquaculture Nutrition. UJNR Department of Commerce, Newport, OR, USA, pp. 19-28.

93. Akiyama T, Arai S (1993) Amino acid requirements of chum salmon fry and supplementation of amino acids to diet. In: Collie MR, McVey JP (Eds), Proceedings of 20th US- Japan Symposium on Aquaculture Nutrition. UJNR Department of Commerce, Newport, OR, USA, pp. 3548.

94. Santiago CB, Lovell RT (1988) Amino acid requirements for growth of Nile tilapia. J Nutr 118(12): 1540-1546.

95. Scott L, Lall SP, Anderson DM (1996) Dietary histidine requirement of Atlantic salmon (Salmo salar) reared in sea water. The CFIA Eastern Nutrition Conference, Dartmouth/Halifax, Canada, CFIA, Canada 259 pp.

96. Rollin X (1999) Critical study of indispensable amino acids requirements of Atlantic salmon (Salmo salar L) fry. University catholique de Louvain, Louvain, Belgium.

97. Moon HY, Gatlin DM III (1991) Total sulfur amino acid requirement of juvenile red drum, Sciaenops ocellatus. Aquaculture 95(1-2): 97-106.

98. Gaber MM, Salem MES, Zaki MA, Nour AM (2016) Amino Acid Requirements of Gilthead Bream (Sparus aurata) Juveniles. WJET 4(3B): 18-24. 


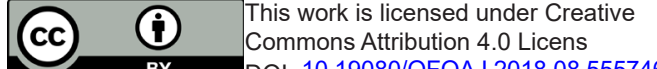

Commons Attribution 4.0 Licens

DOI: 10.19080/OFOAJ.2018.08.555746
Your next submission with Juniper Publishers will reach you the below assets

- Quality Editorial service

- Swift Peer Review

- Reprints availability

- E-prints Service

- Manuscript Podcast for convenient understanding

- Global attainment for your research

- Manuscript accessibility in different formats

( Pdf, E-pub, Full Text, Audio)

- Unceasing customer service

Track the below URL for one-step submission https://juniperpublishers.com/online-submission.php 